\title{
INFLATION DIFFERENTIALS AMONG CZECH HOUSEHOLDS
}

\author{
Pavel Hait \\ Petr Janský
}

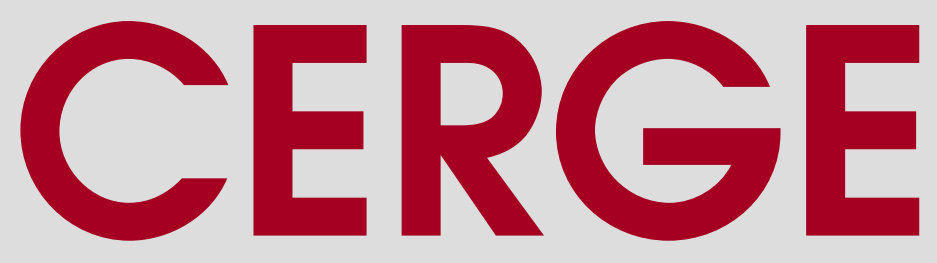




\title{
Working Paper Series $\quad 508$ (ISSN 1211-3298)
}

\section{Inflation Differentials among Czech Households}

\author{
Pavel Hait \\ Petr Janský
}

CERGE-EI

Prague, February 2014 
ISBN 978-80-7343-312-3 (Univerzita Karlova. Centrum pro ekonomický výzkum a doktorské studium)

ISBN 978-80-7344-305-4 (Akademie věd České republiky. Národohospodářský ústav) 


\title{
Inflation Differentials among Czech Households*
}

\author{
Pavel Hait, Petr Janský ${ }^{+}$
}

\begin{abstract}
Inflation rates have traditionally been measured by the annualized percentage change in the price level of a market basket of consumer goods and services purchased by households. The market basket represents the spending patterns of average household. However, households differ in their spending patterns and there are differences in the price changes of various goods and services. Therefore, different households experience different inflation rates. This paper finds that these differences have been significant in the Czech Republic during the period 1995-2010. Only around $60 \%$ of households actually experienced an inflation rate that was similar to the national average. Furthermore, the higher the average inflation rate over time, the lower the percentage of households whose inflation rate was similar to that average. The main determiners of inflation were expenditures for housing and energy and, especially for low-income households and pensioners, expenditures on food and non-alcoholic drinks. In most years, pensioners and low-income households faced significantly higher inflation rates than the average rate for the whole population.
\end{abstract}

\begin{abstract}
Abstrakt
Míra inflace se tradičně měří jako roční procentní změna cenové hladiny zboží ve spotřebním koši. Spotřební koš reprezentuje výdaje průměrné domácnosti. Nicméně, domácnosti se liší v tom, za co utrácejí, a existují i rozdíly v cenových změnách různých zboží a služeb. Různé domácnosti jsou tak vystaveny různým cenovým nárůstům. Tyto rozdíly byly signifikantní v České republice během období 1995-2010. Kolem $60 \%$ domácností bylo vystaveno cenovým nárůstům v podobné výši jako průměrná míra inflace. Navíc čím vyšší byla průměrná inflace, tím menší procento domácností bylo vystaveno nárůstu cen blízko tomuto průměru. Nejdůležitější determinanty inflace byly výdaje za bydlení, energie a, především pro nízkopřijmové domácnosti a domácnosti důchodců, výdaje na jídlo a nealkoholické nápoje. Po většinu sledovaného období byly nízkopř́ijmové domácnosti a domácnosti důchodců vystaveny signifikantně vyšším nárůstům cen, než byla míra inflace.
\end{abstract}

JEL Classification: D12, H22, 131

Keywords: households, inflation, inflation differentials, relative prices

\footnotetext{
* We would like to thank Michal Bauer, Richard Blundell, Alec Chrystal, Libor Dušek, Kamil Galušč́k, Petr Mazouch, Daniel Münich, Filip Pertold, Ondřej Schneider and participants at a Charles University seminar for valuable comments. Support from the Technology Agency of the Czech Republic (TACR TD020188), the CEFRES Fellowship and the Czech Science Foundation (GACR 403/10/1235) is gratefully acknowledged. The data were collected by the Czech Statistical Office. The views expressed here are those of the authors and not necessarily those of our institutions. All errors remaining in this text are the responsibility of the authors.

+ Corresponding author: jansky.peta@gmail.com. Institute of Economic Studies, Faculty of Social Sciences, Charles University in Prague, and CERGE-EI, a joint workplace of Charles University and the Economics Institute of the Academy of Sciences of the Czech Republic, Politických vězñů 7, 11121 Prague, Czech Republic.
} 


\section{Introduction}

The inflation rate was relatively high in the Czech Republic over the last two decades, with yearly rates of around $10 \%$ in the mid-1990s and a $6 \%$ rate in 2008 . From a macroeconomic point of view, these magnitudes of price increases contributed, to the introduction of inflation targeting in 1998, while from a microeconomic point of view, they contributed to a debate about the costs of inflation. An important consideration that has largely been missing from this debate so far is the differential impact that inflation might have on various households, and we aim to fill this gap.

Inflation has a direct influence on the living standards of the whole population. In addition, it has an indirect impact on many households through the so-called indexation of pensions, social benefits or private sector contracts. To be indexed for inflation, these social policies and contracts are often linked with the official rate of inflation; that, however, very often differs from the inflation really experienced by individual households. ${ }^{1}$ This indexation is common in the Czech Republic as well as in many other developed countries as discussed in Fernández (2012) or Whitehouse (2009), including the United States, as discussed in Webb \& Willense (1995). All member countries of the European Union apply some kind of indexation to their pensions, as shown in the 2009 Ageing Report by Bogaert et. al. (2009), which provides a detailed overview of these policies. The indexation of Czech pensions was changed in 2012 and there will be further changes to come, if only due to the temporary status of the current laws, which are valid only until 2015. The current law indexes pensions according to the sum of one third of the growth rate of nominal wages and one third of the growth rate of the inflation rate. Most importantly, from the point of view of this current paper, the current law takes into account only the official rate of inflation for the whole of the Czech Republic, and not a pensioner-specific rate.

The relatively important role of the official inflation rate is arguably driven to a large extent by the underlying assumption that it is the inflation rate faced by, if not all, then at least a majority of households. Yet this assumption might not reflect reality. Indeed, since specific groups of households have different spending patterns, and pay different prices for the same goods and services by shopping in different places, they may experience significantly different inflation rates. These potential differences could be reflected in the relevant policies. $^{2}$

There are prior studies that evaluate inflation rates for different demographic groups. While Prais (1959) laid the theoretical foundations, Snyder (1961) was most likely a pioneer in computing subgroup inflation rates, using US data from 1936 to 1955 to compute the inflation rates for low and high income groups. More recent examples of these types of analyses include Ruiz-Castillo et al. (1999) for Spain, Crawford \& Smith (2002) for the United Kingdom, Oosthuizen (2007) for South Africa, Sugema et al. (2010) for Indonesia. These studies often differ in their specific conclusions, but they generally concur that there is

\footnotetext{
${ }^{1}$ As stated by Czech Statistical Office (2013) on page 4, "Consumer price indices are used for the adjustment of wages, pensions and social income. Last, but not least, this information is also used in connection with the lease agreements or other agreements in which the revision of originally agreed financial performance reflecting the inflation is anchored."

${ }^{2}$ A specific foreign example of how differences in price levels and inflation can be reflected in relevant policies is the so called London allowance (or London weighting), which pays higher public sector wages for Londonbased employees and has been researched for example by Davies \& Wilson (2002).
} 
significant dispersion among the inflation rates experienced by different households at any given point in time. However, there has essentially been no previous research in this area for the Czech Republic or, to the best of our knowledge, for any other Central or Eastern European or former transition country.

This paper analyses inflation rates for individual households in the Czech Republic between 1995 and 2010 and answers the following questions: Are region-specific inflation rates important? How representative is the official inflation rate? Do low-income households and pensioners face higher inflation?

To answer these questions, we apply various methodological approaches in turn. We look for the difference between price expenditures of Prague households when computed in two different ways. We first of all use nationwide prices to compute the inflation rate for Prague households, and then compare this to an inflation rate obtained using Prague prices instead of nationwide ones. We also estimate the share of the population for which the average inflation rate can be considered representative and examine the relationship between the average inflation rate and its representativeness. We then discuss and estimate two different approaches to calculating the inflation rates. Finally, we analyse inflation differentials for the subgroups of low-income and pensioner households and identify the main determiners of higher inflation.

The layout of the paper is as follows: the methodology is explained in Section 2; the main datasets used for the analysis are described in Section 3; the bias caused by the application of nationwide prices instead of region-specific prices is evaluated in Section 4; the representativeness of the official Czech inflation rate is measured in Section 5; Section 6 discusses various possibilities for computing subgroup inflation rates; Section 7 analyses the magnitudes and drivers of subgroup inflation rates for pensioners and low-income households; and the conclusion is found in Section 8.

\section{Methodology}

This section discusses inflation rate measurement and introduces terminology that will be used throughout the paper. The official inflation rate is the inflation rate published by the Czech Statistical Office (CZSO). The specific inflation rate is the inflation rate to which a given household is exposed. The subgroup inflation rate is the inflation rate which impacts a given subgroup of households. When the subgroup is a whole population of households, the subgroup inflation rate is the aggregate inflation rate.

When estimating inflation rate in order to measure real changes in the cost of living, we have to deal with the problem that, as noted by Hobijn \& Lagakos (2005, page 582 ), it is well known from price index theory that calculating an exact index of the cost of living is not feasible. Instead, the measure of the average change in the cost of living in a period $t$ is usually approximated by a change in the Consumer Price Index (CPI), which is calculated by the Laspeyres index:

(1) $C P I \Delta_{t}=\frac{\sum_{a=1}^{n} p_{a, t} q_{a, t-1}}{\sum_{a=1}^{n} p_{a, t-1} q_{a, t-1}}-1$ 
where $C P I \Delta_{t}$ is the change in the CPI in period $t, q_{a, t}$ is the quantity of good or service $a$ consumed in period $t$ in a whole economy, $p_{a, t}$ price of good or service $a$ in period $t, n$ is the number of different goods or services. ${ }^{3}$

As Crawford \& Smith( 2002) discuss, for example, the CPI is not a true cost-of-living index, because a cost-of-living index measures the average change in prices with reference not to a fixed list of demands, but to a fixed standard of living. Since the CPI assumes there is no substitution when relative prices change, it corresponds to the upper limit of the true growth of the cost-of-living index. ${ }^{4}$ When there are no significant changes in prices, it can be assumed that the bias is low, since households are not motivated to substantially change their expenditure patterns.

Unfortunately, the data on quantities consumed that are necessary for the evaluation of formula (1) are not usually available, only data on expenditure for a given good or service. Also, data on prices are usually less costly to obtain than data on expenditures, and therefore price data are more readily available than expenditure data. With these limitations, the CPI change is computed as:

(2) $C P I \Delta_{t}=\frac{\sum_{a=1}^{n} E_{a, b} \frac{p_{a, t}}{p_{a, b}}}{\sum_{a=1}^{n} E_{a, b} \frac{p_{a, t-1}}{p_{a, b}}}-1$

where $E_{a, t}=p_{a, t} q_{a, t}$ is the expenditure on a good or service $a$ in at time $t$ in a whole economy, $t=b$ is the base time period.

The CZSO changes the base period approximately every five years, as this is their interval for conducting major updates to the expenditure structure. ${ }^{5}$ In the US, according to Greenlees \& Mason (1996), the index is updated approximately every 10 years. As underlined by Hobijn \& Lagakos (2005, page 583), infrequent updating of the base period can be a major source of substitution bias, because it means that the CPI does not take properly into account the fact that people substitute goods that become relatively cheaper for goods that become relatively more expensive. In this paper, the expenditures are updated in every period when the inflation rate is computed (so $b=t-1$ is set). This has two advantages, as in Hobijn \& Lagakos (2005, page 583): the analysis is not limited by dependence on the selection of a particular base period, and the substitution bias is reduced. For our computations the aggregate inflation rate at time $t$ is defined as:

(3) $\pi_{t}=\frac{\sum_{a=1}^{n} E_{a, t-1} \frac{p_{a, t}}{p_{a, t-1}}}{\sum_{a=1}^{n} E_{a, t-1}}-1$

Defining the relative price change of a specific good or service $a$ at the time $t$ as:

(4) $r_{a, t}=\frac{p_{a, t}}{p_{a, t-1}}-1$

\footnotetext{
${ }^{3}$ Alternatively, there is the GDP deflator, defined as GDP deflator $\Delta_{t}=\frac{\sum_{a=1}^{n} p_{a, t} q_{a, t}}{\sum_{a=1}^{n} p_{a, t-1} q_{a, t}}-1$, and computed by the Paasche index. Unlike the CPI, the basket of goods for the GDP deflator is allowed to change from year to year and therefore can account for substitution bias.

${ }^{4}$ This is discussed in Abraham et al. (1998, page 2) or Crawford \& Smith (2002, page 3), and an extensive review of sources of CPI bias in measuring the cost-of-living index is provided in Garvey \& Murphy (2004, pages 11 and 12). For example, according to Boskin et al. (1998, page 44), the US CPI overestimates the true cost-ofliving index by $1.1 \%$.

${ }^{5}$ An expert from the CZSO, Iva Šedivá, provided us with the information that between 1999 and 2012, there were updates in 1999, 2005, and 2009.
} 
The definition of an aggregate inflation rate can be rewritten as:

(5) $\pi_{t}=\frac{\sum_{a=1}^{n} E_{a, t-1} \frac{p_{a, t}}{p_{a, t-1}}}{\sum_{a=1}^{n} E_{a, t-1}}=\frac{\sum_{a=1}^{n} E_{a, t-1}\left(r_{a, t}+1\right)}{\sum_{a=1}^{n} E_{a, t-1}}-1=\frac{\sum_{a=1}^{n} E_{a, t-1} r_{a, t}}{\sum_{a=1}^{n} E_{a, t-1}}$

Following (5), the specific inflation rate of a household $h$ at time $t$ can be defined as:

(6) $\pi_{h, t}=\frac{\sum_{a=1}^{n} E_{h, a, t-1} r_{a, t}}{\sum_{a=1}^{n} E_{h, a, t-1}}$

where $E_{h, a, t}$ is the expenditure of a household $h$ for a good or service $a$ at time $t$.

There are two possible approaches to calculating the aggregate or subgroup inflation rates: democratic and plutocratic averages. One of the first authors to extensively discuss the problem of multiple possibilities when computing the aggregate or subgroup inflation rate was Prais (1959), while the differences between democratic and plutocratic averages were more recently discussed by Artsev et al. 2006) and by Crawford \& Smith (2002). The plutocratic average resembles the official inflation rate in that it is weighted by households' total expenditures, while the democratic average is a democratically-weighted average, where each household has the same weight. Formally, the democratic average for a subgroup $x$ at time $t$ is the arithmetic average of specific inflation rates at time $t$ of all households from $x$ :

(7) $D_{x, t}=\frac{\sum_{t=1}^{m} \pi_{h, t}}{m}$

where $\pi_{h, t}$ is the specific inflation rate of household $h$ (in this case, belonging to subgroup $x$ ) at time $t, m$ is the number of households in subgroup $x$.

The plutocratic average for subgroup $x$ at time $t$ is defined as:

(8) $\pi_{x, t}=\frac{\sum_{a=1}^{n} E_{x, a, t-1} r_{a, t}}{\sum_{a=1}^{n} E_{x, a, t-1}}$

Definition (8) is very similar to the definition of the specific inflation rate (6), but instead of the expenditures of household $h$ for good or service $a$ at time $t\left(E_{h, a, t}\right)$, the expenditures of subgroup $x$ for good or service $a$ at time $t$ is used $\left(E_{x, a, t}\right)$. Households are weighted equally in the case of (7), the democratic average, whereas in the case of (8), the plutocratic average, households with higher expenditures have higher weights and vice versa. The CPI change is constructed as a plutocratic average. It is usually easier to compute in this way, as only the price indices and the aggregated expenditure shares of goods and services are needed, whereas for the computation of the democratic average the specific inflation rates for every household must be evaluated, as discussed for example in Artsev et al. (2006) and Kokoski (2000). The difference between the plutocratic and the democratic average is called plutocratic bias.

\section{Data}

To compute the variables of interest using the formulas defined in the previous section, we need data on household characteristics and expenditures on various goods and services, as well as data on relative price developments for various goods and services. These data sets come from the CZSO in the form of the Household Budget Survey (HBS) and in price data gathered for the purpose of the Consumer Price Index (CPI). We used the HBS annual data for 1994 to 2009, and the CPI nationwide price indices from 1994 to 2010, as well as the CPI price indices for the Prague region from 2001 to 2010.

The HBS contains very detailed data on the income, expenditures, and other characteristics of a sample of Czech households, and has been previously used in recent microeconomic 
analyses such as Dušek \& Janský (2012). Specifically, the data provides information for around 250 expenditure groups (goods and services), approximately60 demographic identifiers, and around 30 income items, for a representative sample of approximately 3000 households in the Czech Republic. It is the most detailed dataset of its kind for the Czech Republic. The composition of the sample is amended, usually annually, to maintain a high level of representativeness. ${ }^{6}$ The size of the survey and the number of observed attributes changes slightly year to year. There are some potential confounders of the representativeness of HBS, but we do not consider them particularly influential, especially in the data collected since 2006, not least on the basis of analysis in Dybczak et al. (2010). ${ }^{7}$ Let us also note that the sample for the household budget survey was selected by purposive quota sampling. The designers of the survey have made efforts to make it as similar to a random sample as possible, but nevertheless its characteristics are not the same as those of a random sample, in general. One implication of this suboptimal sampling is that the results of hypothesis testing on the data might be biased or misleading. However, we believe that our use of the data is consistent and in line with the efforts of CZSO to make the sample resemble a random sample as closely as possible, as well as with previous uses of the data such as Dybczak et al. (2010).

This paper uses some HBS variables for sorting households into subgroups. Data about financial expenditure are fully utilised. In-kind income and expenditure are not used in the computation of various inflation rates. For most of the goods and services, the survey does not contain the number of units bought, but only expenditure on these goods and services. Therefore, a dataset of prices is needed in order to be able to evaluate the inflation rates.

The CZSO collects price data on a monthly basis for the purpose of the CPI for all units in the consumer basket, which has around 700 units. These detailed data are, however, only for the internal purposes of CZSO including the computation of the Harmonised Index of Consumer Prices (introduced by Eurostat and employed by the European Central Bank for the purposes of monetary policy in Eurozone). For this research, it was only possible to obtain the monthly price indices of 145 groups of goods and services, from 1991 to 2010, aggregated for the whole Czech Republic. The equivalent price indices specific to the Prague region for 2001-2011 were also available. These are the most detailed time-series datasets of Czech prices that are available to researchers. The number of price indices allocated to

\footnotetext{
${ }^{6}$ Every household in the sample is allocated a specific coefficient (COEF) that indicates its weight in the sample. These COEFs are employed in order to obtain a representative sample. The existence of COEFs makes computations more demanding, as households must be always weighted by their COEFs. In this paper, this weighting is always included; sometimes it is explicitly described.

${ }^{7} \mathrm{~A}$ short discussion of potential confounders of HBS resulting in its potential non-representativeness, most relevant to the pre-2006 data, follows. First, institutional households and homeless people are not included in the survey by the European Communities (2004). Also, the sample might be too small because the ratio of the number of households surveyed to the number of households in the actual population was the second lowest among 13 European countries according to European Communities (2004). Furthermore, as Crawford \& Smith (2002) discuss, systematic over- or under-reporting of expenditures can occur in this type of data collection, due to forgetfulness (e.g. consumption outside the home), active concealment (e.g. receipt from a beauty studio), and guilt (e.g. cigarettes). And, since some expenditures are recorded monthly, large and infrequent purchases may be underestimated. The treatment of these confounders is beyond the scope of this analysis, and it is assumed in line with Dybczak et al. (2010) and other similar studies that they are not very significant.
} 
every first-level Classification of Individual Consumption by Purpose (COICOP) expenditure category varies. $^{8}$

Since the data provided from the HBS are annual, no use is made of the fact that the price index data are available on a monthly basis; only the annual averages are used in the inflation computations. There is a wide dispersion among the development of relative prices even if we examine only the highly aggregated cumulative price indices for 12 groups of goods and services according to the first level of the COICOP from 1994 to 2010. Using 1994 as a base equal to $100 \%$, housing and fuel costs and health costs grew by more than $200 \%$. In contrast, the average nominal prices of clothing and footwear were the same in 1994 as in 2010 , and furnishing and household equipment and maintenance grew by just $16 \%$ over the period.

The structure of the expenditure breakdown in the HBS is different from the price indices breakdown provided by the CZSO. Therefore we constructed a conversion table linking variables from the financial expenditures of HBS to the specific price index from the set of 145 price indices in order to compute inflation rates as defined in the previous section. The conversion was quite clear for many variables, since the name of the variable in the expenditures list and the price index are the same or very similar. As the number and structure of observed variables within the financial expenditures in HBS varies somewhat from year to year, conversion tables for different years sometimes vary slightly.

\section{Nationwide versus Prague prices}

This section analyses the size of the bias in inflation rate computation that is introduced by assuming that households from different regions within a country face the same (i.e. nationwide) prices. There are existing papers that evaluate inflation rates with respect to the region where the household is located (for example Garner et al., 1996, page 36)), but these assume the same nationwide prices for specific goods for all households, so the differences in inflation rates they observe are attained owing to regional differences in consumption patterns. Previous studies admit that there are price differences for the same goods in different regions Čadil et al. (2012, page 10) and shops O'Donoghue et al. (2007), but, as argued by Hobijn \& Lagakos (2005), the assumption that all households encounter the same prices for the same goods and services is very widespread because regional price indices are only rarely available.

As the available data make it possible, we compare inflation rates for Prague households using both nationwide and Prague price indices for years 2002-2010. Table 1 shows this comparison. The use of nationwide prices generally seems to overestimate the price increases, when compared to the values using Prague prices, with the exception of two

\footnotetext{
${ }^{8}$ Distribution of price indices among expenditure categories according to the first level of COICOP categories (number of price indices in the brackets): 1. Food, Non-Alcoholic Beverages (14); 2. Alcoholic Beverages, Tobacco (7); 3. Clothing, Footwear (9); 4. Housing, Water, Electricity, Gas, Other Fuels (17); 5. Furnishings, Household Equipment, Routine Household Maintenance (17); 6. Health (10); 7. Transport (16); 8. Communication (4); 9. Recreation, Culture (24); 10. Education (6); 11. Restaurants, Hotels (5); 12. Miscellaneous Goods, Services (16).
} 
years, 2003 and $2009 .{ }^{9}$ So using Prague prices instead of nationwide prices in calculations for the past decade would result in lower inflation rates being reported for Prague households, and this would likely better reflect the reality experienced by Prague households.

Table 1: Prague households democratic average inflation rates for various price indices

\begin{tabular}{|l|l|l|l|l|l|l|l|l|l|l|}
\hline $\begin{array}{l}\text { Democratic average } \\
\text { inflation rate }\end{array}$ & $\mathbf{2 0 0 2}$ & $\mathbf{2 0 0 3}$ & $\mathbf{2 0 0 4}$ & $\mathbf{2 0 0 5}$ & $\mathbf{2 0 0 6}$ & $\mathbf{2 0 0 7}$ & $\mathbf{2 0 0 8}$ & $\mathbf{2 0 0 9}$ & $\mathbf{2 0 1 0}$ & Avg. \\
\hline $\begin{array}{l}\text { Prague households, } \\
\text { Prague price indices }\end{array}$ & $1.30 \%$ & $0.68 \%$ & $2.55 \%$ & $1.48 \%$ & $2.20 \%$ & $2.36 \%$ & $6.64 \%$ & $1.80 \%$ & $1.27 \%$ & $2.25 \%$ \\
\hline $\begin{array}{l}\text { Prague households, } \\
\text { nationwide price } \\
\text { indices }\end{array}$ & $1.74 \%$ & $-0.01 \%$ & $2.78 \%$ & $1.71 \%$ & $2.59 \%$ & $2.78 \%$ & $7.17 \%$ & $1.77 \%$ & $1.83 \%$ & $2.48 \%$ \\
\hline $\begin{array}{l}\text { All households, } \\
\text { nationwide price } \\
\text { indices }\end{array}$ & $1.22 \%$ & $-0.32 \%$ & $2.69 \%$ & $1.61 \%$ & $2.54 \%$ & $2.56 \%$ & $6.73 \%$ & $1.50 \%$ & $1.34 \%$ & $2.16 \%$ \\
\hline
\end{tabular}

The Prague region is overall very distinct from other Czech regions and therefore the bias for the Prague region caused by the usage of nationwide price indices could be assumed to be an upper limit for any other regional biases that we cannot examine due to a lack of regional data. Still, on the basis of the Prague analysis, it seems clear that the bias introduced by the assumption that households from all regions face the same inflation is substantial.

This bias is not usually taken into account in research, but more importantly, is not taken into account in public policies such as the indexation of pensions, which aim to keep up with the rising cost of living. Further analysis that took into account not only these region-specific inflation differentials, but also region-specific price levels that we do not study here, could lead to recommendations for region-specific indexation. As with any policy change, this should be further evaluated on the basis of the presumed benefits and costs of, for example, the policy's implementation and associated administration.

\section{Average inflation rate representativeness}

This section analyses the representativeness of the average inflation rate since, as noted by Leicester et al. (2008), any measure of inflation is necessarily only an average of the experience of different households and may not be particularly representative of what is happening for any household in particular. For the purposes of this paper, the aggregate democratic inflation rate is considered representative for a given household if the specific inflation rate of that household is "very close" to it. Leicester et al. (2008) proposed two measures of "closeness" and applied them to the UK data. The second measure is also used on UK data by Crawford \& Smith (2002) and on Israeli data by Artsev et al. (2006). Both of these measures are applied in this paper and so our results can be compared with those for the UK, and partially with those for Israel.

Leicester et al. (2008) define the first measure (Measure 1) as the answer to the question of how many households have an inflation rate that is more than 25 per cent away from the

\footnotetext{
${ }^{9}$ Furthermore, using a standard t-test with the Prague household subsample, the difference between the democratic average inflation rate using nationwide prices and Prague prices is significantly negative in all cases at $99.9 \%$ confidence level, except for 2003 and 2009. In 2003, it is significantly positive, while in 2009 it is not significantly different from zero.
} 
mean inflation rate in each year. The second measure (Measure 2 ) is then the answer to the question of how many households experience inflation that is more than 1 percentage point away from the mean. The two measures will therefore produce different results and, as Leicester et al. (2008) note, the former will tend to suggest that many households are far from the mean when inflation is very low, whereas the latter will suggest many households are far from the mean when inflation is very high.

Formally, we define the two measures in the following way. Measure 1:

$$
\begin{aligned}
& \text { if } i \geq 0: i_{h} \in\langle 0.75 i ; 1.25 i\rangle \Leftrightarrow i_{h} \in C \\
& \text { if } i<0: i_{h} \in\langle 1.25 i ; 0.75 i\rangle \Leftrightarrow i_{h} \in C
\end{aligned}
$$

Measure 2:

$$
i_{h} \in(i-1 \% ; i+1 \%) \Leftrightarrow i_{h} \in C
$$

where $C$ is the subset of specific inflation rates which are "close" to the democratic inflation rate, $i$ is the democratic inflation rate, $i_{h}$ is the specific inflation rate for a household $h .{ }^{10}$ Table 2 shows the estimated ratios of representativeness and the democratic average inflation rate for 1995-2010. The average proportions of households fulfilling measures 1 and 2 for closeness over the whole period are 53\% and 64\%, respectively. In the UK, based on Leicester et al. (2008), in 1995-2008, the ratios were $46 \%$ and $52 \%$ respectively. ${ }^{11}$ In Israel, in 1999-2005, the average measure 2 ratio was 58\% Artsev et al. (2006).

Table 2: Estimated ratios of representativeness of official inflation rate over time (\%)

\begin{tabular}{|l|l|l|l|l|l|l|l|l|l|}
\hline & 1995 & 1996 & 1997 & 1998 & 1999 & 2000 & 2001 & 2002 & \\
\hline Democratic inflation rate & 9.2 & 9.3 & 8.8 & 11.1 & 1.9 & 3.1 & 5.0 & 1.2 & \\
\hline Measure 1 & 97.4 & 93.4 & 87.7 & 74.1 & 47.6 & 41.5 & 66.3 & 26.3 & \\
\hline Measure 2 & 73.2 & 65.9 & 56.2 & 31.5 & 77.8 & 54.2 & 55.7 & 72.3 & \\
\hline & 2003 & 2004 & 2005 & 2006 & 2007 & 2008 & 2009 & 2010 & Avg. \\
\hline Democratic inflation rate & -0.3 & 2.7 & 1.6 & 2.5 & 2.6 & 6.7 & 1.5 & 1.3 & 4.3 \\
\hline Measure 1 & 10.3 & 62.4 & 36.6 & 45.8 & 44.4 & 65.0 & 29.1 & 27.6 & 53.5 \\
\hline Measure 2 & 87.0 & 79.5 & 73.8 & 64.1 & 64.1 & 42.0 & 64.9 & 67.3 & 64.3 \\
\hline
\end{tabular}

Table 2 also confirms our expectations that the two measures will vary, and in what ways. For example when the inflation was relatively low around 2003, Measure 1 does suggest that many households are far from the mean, whereas when inflation was relatively very high in 2008, Measure 2 suggests that many households are far from the mean.

Crawford \& Smith (2002) further analysed whether the magnitude of an aggregate democratic inflation rate was significantly associated with lower representativeness, using

\footnotetext{
${ }^{10}$ As described earlier, the representativeness of a household in a sample is determined by its COEF number and we use these as weights. A procedure is applied for both measures in which all coefficients belonging to the households whose specific inflation rate falls into $C$ are summed, and the sum is divided by the sum of coefficients of all households in the sample. Formally: $R=\frac{\sum_{i=1}^{n} c_{i}}{\sum_{j=1}^{m} c_{i}}$, where $R$ is the estimated ratio of population whose specific inflation rate is close to the democratic average inflation rate, $n$ is the number of households whose computed specific inflation rate is close to the democratic average inflation rate, $m$ is the total number of households in the sample, and $c_{i}$ is the COEF of the household $i$.

${ }^{11}$ Leicester et al. (2008) provided a chart on page 22, but no exact numbers, so we have estimated this average from their chart.
} 
UK data from the period 1975-1999, by using the ordinary least squares to regress the Measure 2 ratio on the aggregate democratic inflation rate. The value of the estimated coefficient of aggregate democratic inflation rate was -1.7 with standard error 0.5 . Artsev et al. (2006) performed the same test on the Israeli 1999-2005 data, and the value of the estimate was $-0.7 .^{12}$ The result of this regression estimated on the Czech data is -2.5 .

The estimated coefficient is statistically significant at the $99 \%$ confidence level ( $p$-value 0.009 ), and is lower than that for the UK and Israeli data. The regression is based only on a very small number of observations (16) and the data analysis also indicated possible heteroskedasticity. The $p$-value of the Breusch-Pagan test is 0.055 . Running the regression with robust standard errors, the estimate is still significant at the $95 \%$ confidence level ( $p$ value 0.028).

Overall, the average inflation rate was representative for only around $60 \%$ of the Czech households, with significant changes over time and depending on the measure used. We find a statistically significant negative association between the average inflation rate and the representativeness, approximated by Measure 2 ratio, which is in line with the previous results on the UK and Israeli data.

\section{Plutocratic versus democratic average inflation rate}

This section presents empirical evidence on aggregate plutocratic and democratic inflation rates and thus continues the discussion of these two terms begun in Section 2 .

Table 3 provides a comparison of the annual aggregate democratic and plutocratic averages. It includes also the difference between the two averages, the so called plutocratic bias, as well as the official inflation rate and also the GDP deflator.

Table 3: Average plutocratic, democratic, official inflation rate and plutocratic bias

\begin{tabular}{|l|l|l|l|l|l|l|l|l|l|}
\hline & 1995 & 1996 & 1997 & 1998 & 1999 & 2000 & 2001 & 2002 & \\
\hline Plutocratic average & 8.9 & 8.9 & 8.4 & 10.1 & 1.9 & 3.8 & 4.6 & 1.0 & \\
\hline Democratic average & 9.2 & 9.3 & 8.8 & 11.1 & 1.9 & 3.1 & 5.0 & 1.2 & \\
\hline Plutocratic bias & -0.2 & -0.3 & -0.4 & -0.9 & 0.0 & 0.7 & -0.4 & -0.3 & \\
\hline Official inflation rate (CPI) & 9.1 & 8.8 & 8.5 & 10.7 & 2.1 & 3.9 & 4.7 & 1.8 & \\
\hline GDP deflator & 9.9 & 7.9 & 9.7 & 2.5 & 1.4 & 4.6 & 2.6 & 9.9 & \\
\hline & 2003 & 2004 & 2005 & 2006 & 2007 & 2008 & 2009 & 2010 & Avg. \\
\hline Plutocratic average & -0.4 & 2.5 & 1.3 & 2.2 & 2.3 & 6.1 & 1.1 & 1.1 & 4.0 \\
\hline Democratic average & -0.3 & 2.7 & 1.6 & 2.5 & 2.6 & 6.7 & 1.5 & 1.3 & 4.3 \\
\hline Plutocratic bias & -0.1 & -0.2 & -0.3 & -0.4 & -0.3 & -0.7 & -0.4 & -0.2 & -0.3 \\
\hline Official inflation rate (CPI) & 0.1 & 2.8 & 1.9 & 2.5 & 2.8 & 6.3 & 1.0 & 1.5 & 4.3 \\
\hline GDP deflator & 0.9 & 4.0 & -0.3 & 0.5 & 3.3 & 1.9 & 2.3 & -1.6 & 3.0 \\
\hline
\end{tabular}

Source: Plutocratic average and bias and democratic average is computed as explained in the text, and the official CPI and the GDP deflator is taken from the CZSO

\footnotetext{
${ }^{12}$ Variance was not provided by Artsev et al. (2006) and so the statistical significance cannot be judged.
} 
The average of the aggregate plutocratic inflation rate over the whole period is $4.0 \%$; for the democratic inflation rate $4.3 \%$; for the official inflation rate $4.3 \%(\mathrm{CPI}) .{ }^{13}$ The average of the GDP deflator is lower than of the CPI as expected due to the substitution bias of the CPI. The plutocratic bias, which is the democratic average subtracted from the plutocratic average, is negative for most of the period. ${ }^{14}$ One of the implications is that better offhouseholds faced a lower inflation rate than poorer households in most years. A summary of 12 empirical studies about the plutocratic bias is discussed in Ley (2005) and the conclusion is that the sign and magnitude of the bias varies heavily across countries and years.

Oosthuizen (2007) argues that the weighting methodology (democratic or plutocratic average) should be selected based on the purpose for which the computed inflation rate is used. So in the case of monitoring economy-wide consumer price inflation, the price index should reflect the structure of economy-wide consumer spending and therefore the use of the plutocratic average is recommended. On the other hand, the democratic average should be used where the price index is used in relation to one given population subgroup; for example, for adjusting pensions in order to maintain the real purchasing power of pensioners. Therefore the democratic averages are used to represent the subgroup inflation rates in this study. As argued by Leicester et al. (2008), there is no reason why high-income families should have more weight in determining subgroup inflation rates.

As discussed by Oosthuizen (2007) and Moulton \& Stewart (1999), there are a number of problems that can affect the calculation of subgroup inflation rates. The two most important seem to be, first, that the number of households in a subgroup is generally smaller than the total number of households (so the result might not be representative); and, second, that the data on prices are collected from shops that are chosen as representative of the whole population, and this might not be applicable to a particular subgroup. ${ }^{15}$ Subgroup inflation rates may be biased for these reasons. For the Czech Republic, we believe that the bias caused by the second of these issues might be more important than that caused by the first, since both of the subgroups we analyse in the next section are represented by hundreds of observations in HBS every year. ${ }^{16}$

\section{Pensioner household and low-income household subgroups}

In this section we analyse subgroup inflation rates for pensioner households and low-income households as well as the main influences on these rates. We define a pensioner household

\footnotetext{
${ }^{13}$ In theory, using the same dataset and methodology as the CZSO should imply that the plutocratic average equals the official inflation rate. In practice, we use a different dataset (as the most detailed CZSO dataset is not available to researchers) and different methodology (one difference that we are aware of is that we update the expenditure shares every year whereas the CZSO updates these roughly every five years; this should lead to a lower substitution bias in the aggregate plutocratic inflation rate). These differences might explain why the aggregate plutocratic inflation rate shown here is on average lower than the official inflation rate.

${ }^{14}$ At a $99 \%$ confidence level, the plutocratic bias was significantly negative for all years except 1999, when the difference was not significant, and 2000 , when it was significantly positive.

${ }^{15}$ According to Ley (2005, page 641), the Indian Ministry of Statistics and Programme Implementation, which computes several subgroup inflation rates, solved this problem by collecting distinctive prices for every subgroup (based on a sample of shops visited by the respective subgroup).

${ }^{16}$ The bias caused by the second reason might be important, but there is no easy way we could test this with the currently available data. It might theoretically be tested by comparing the CPI prices with householdspecific unit values derived from the HBS, and we consider this an interesting area for future research.
} 
in line with the CZSO as a household in which there are no economically active members and whose head is a pensioner. Low-income households were defined in various ways in previous studies, and we present these in Table 4.

Table 4. Various definitions of low-income households

\begin{tabular}{|l|l|}
\hline Study & Definition \\
\hline \multirow{4}{*}{ (Sugema et al. 2010) } & $\begin{array}{l}\text { Per capita income of a household below specified absolute } \\
\text { threshold }\end{array}$ \\
\hline (Artsev et al. 2006) & Per capita net income in lowest 10\% of the distribution \\
\hline (Garvey \& Murphy 2004) & Lowest 10\% of the households income distribution \\
\hline (Crawford \& Smith 2002) & Lowest 10\% of the households income distribution \\
\hline \multirow{3}{*}{ (Garner et al. 1996) } & 1.Income below given absolute poverty threshold \\
\cline { 2 - 2 } & 2. Expenditures below given absolute poverty threshold \\
\cline { 2 - 2 } & 3. Participation in selected welfare programs \\
\hline (Blank \& Blinder 1985) & Lowest 20\% of the households income distribution \\
\hline (Hagemann 1982) & Income of a household below absolute specified threshold \\
\hline
\end{tabular}

We consider the status of low-income as having a relative rather than absolute meaning: a low-income household is defined as one with an income in the lowest $10 \%$ of the income distribution in a given year. ${ }^{17}$ Once again, we ensure representativeness. ${ }^{18}$ Table 5 compares democratic inflation rates for three groups: the so called aggregate covers the whole population, whereas the other two democratic inflation rates focus on pensioners and lowincome households.

Table 5: Democratic inflation rates - aggregate, low-income households, pensioners

\begin{tabular}{|l|l|l|l|l|l|l|l|l|l|}
\hline & 1995 & 1996 & 1997 & 1998 & 1999 & 2000 & 2001 & 2002 & \\
\hline Aggregate & 9.2 & 9.3 & 8.8 & 11.1 & 1.9 & 3.1 & 5.0 & 1.2 & \\
\hline Pensioner households & 10.0 & 9.8 & 9.8 & 12.0 & 1.9 & 3.4 & 6.1 & 1.6 & \\
\hline Low-income households & 9.3 & 9.8 & 9.2 & 12.9 & 2.2 & 3.6 & 6.5 & 2.1 & \\
\hline & 2003 & 2004 & 2005 & 2006 & 2007 & 2008 & 2009 & 2010 & Avg. \\
\hline Aggregate & -0.3 & 2.7 & 1.6 & 2.5 & 2.6 & 6.7 & 1.5 & 1.3 & 4.3 \\
\hline Pensioner households & -0.1 & 3.0 & 2.1 & 3.3 & 2.5 & 8.1 & 1.6 & 1.4 & 4.8 \\
\hline Low-income households & -0.2 & 3.1 & 2.3 & 3.7 & 2.6 & 8.5 & 1.4 & 1.5 & 4.9 \\
\hline
\end{tabular}

The average of the aggregate democratic inflation rate for the whole sample for the sample period is, as mentioned earlier, $4.3 \%$, while it is $4.8 \%$ for low-income households, and $4.9 \%$ for pensioner households. Both subgroup inflation rates are higher than the aggregate rate in most years. ${ }^{19}$ Using the same data as in Table 5, and considering 1994 as a base year with a price level equal to $100 \%$ for all groups of households, the cumulative inflation in 2010 would be $193 \%$ for the whole sample, $209 \%$ for pensioner households, and $213 \%$ for lowincome households. These differences seem substantial to us, and in our opinion deserve

\footnotetext{
${ }^{17}$ This threshold is selected in compliance with a number of other authors who run similar analyses (Table 4).

${ }^{18}$ Specifically, we ensure the best possible representativeness by defining the $10 \%$ threshold so that the sum of COEFs of households with incomes below that threshold equalled $10 \%$ of the total sum of COEFs.

${ }^{19}$ Using Welch's one-tailed t-test, the pensioner rate is significantly greater than the aggregate rate at a $95 \%$ confidence level in every year except 1999, 2007, 2009 and 2010. Almost the same holds for low-income households, whose inflation rate is significantly greater except in 2007, 2009, and 2010. Also, it can be hypothesised that low-income households face the same inflation rate as pensioner households. However, using Welch's two-tailed t-test, the rates are, at the 95\% confidence level, not significantly different only in 6 of the years studied: 1996, 2000, 2003, 2007, 2009, and 2010.
} 
the attention of policy makers, for example, when planning the indexation of pensions or social benefits.

Let us compare our results with the existing literature for other countries. Looking only at papers that analyse periods of at least 5 years, many have concluded that low-income households faced a higher than average inflation rate (for example, Stewart, 2008 on US data, Garvey \& Murphy ,2004 on Irish data, and Sugema et al. ,2010 on Indonesian data), some concluded that they faced overall the same inflation rate as the average (Artsev et al. ,2006 on Israeli data), and some concluded that they faced lower inflation (Crawford \& Smith 2002 on UK data). Blank \& Blinder (1985) examined a very long period from 1947 to 1982 using US data, and concluded that on average there is no difference. Generally, poor households are less able to substitute when the price of the goods and services they buy increases. Therefore, the bias of the CPI as an estimator of true inflation rates (caused by the assumption of constant expenditure patterns as price changes) is lower for them than for richer households. Furthermore, the aggregate inflation rate is biased upward more than the low-income households' inflation rate. Therefore, our estimated difference between results for the subgroups and for the whole sample might be even greater in reality. The same argument holds for pensioners, if only because, on average, they also belong to poorer households.

The results for pensioners are similarly varied. For example, Hobijn \& Lagakos (2005) concluded based on US data that pensioners faced on average a higher inflation rate, while Crawford \& Smith (2002) arrived at the opposite conclusion based on UK data, and Lieu et al. (2004) found on average no difference between the two rates, based on data from Taiwan.. While summarising various studies on subgroup price indices, Oosthuizen (2007) concluded that no single group experiences consistently higher or lower rates of inflation in the long run, relative to other groups. Assuming that price indices develop differently, and that subgroups have different spending patterns among countries, there is no reason that there should be worldwide similar trends among subgroup inflation rates in comparison to the national aggregate inflation rates.

To determine the biggest contributors to the inflation rate to which a subgroup is exposed, the relative contribution of expenditure on a specific good or service $i$ to the plutocratic inflation rate at the period $t$ for sub-population $x$ can be calculated as:

(9) $\quad R_{x, t, a}=\frac{E_{x, i, t-1} r_{i, t}}{\left|\sum_{a=1}^{n} E_{x, a, t-1} r_{a, t}\right|}$

For a better aggregated illustration, we divide all goods and services monitored by HBS into 12 groups according to the first level of COICOP. The relative contribution of expenditure on a specific group of goods and services $k(k \in\{1,2, \ldots, 12\})$ to the subgroup plutocratic inflation rate at a period $t$ for sub-group $x$ is calculated as:

$$
R_{x, t, k}=\frac{\sum_{i=1}^{m} E_{x, i, t-1} r_{i, t}}{\left|\sum_{a=1}^{n} E_{x, a, t-1} r_{a, t}\right|}
$$

where $m$ is the total number of specific goods/services in the group $k$. The absolute contribution of expenditure on a specific group of goods and services $k(k \in\{1,2, \ldots, 12\})$ to the subgroup plutocratic inflation rate at a period $t$ for sub-group $x$ can be defined $a s^{20}$ :

\footnotetext{
${ }^{20}$ Since the weight of a household in the whole sample is determined by its COEF, the expenditures are weighted according to the COEFs of the households in order to maintain representativeness (this is not shown in the equations).
} 
(11)

$$
A_{x, t, k}=\left(\frac{\sum_{i=1}^{m} E_{x, i, t-1} r_{i, t}}{\sum_{a=1}^{n} E_{x, a, t-1} r_{a, t}}\right) \pi_{x, t}=\left(\frac{\sum_{i=1}^{m} E_{x, i, t-1} r_{i, t}}{\sum_{a=1}^{n} E_{x, a, t-1} r_{a, t}}\right)\left(\frac{\sum_{a=1}^{n} E_{x, a, t-1} r_{a, t}}{\sum_{a=1}^{n} E_{x, a, t-1}}\right)=
$$

$$
\frac{\sum_{i=1}^{m} E_{x, i, t-1} r_{i, t}}{\sum_{a=1}^{n} E_{x, a, t-1}}
$$

Table 6 shows the absolute contribution of various expenditures of the whole sample, pensioner households, and low-income households towards their inflation rates. The biggest "increasers" (expenditure on a given subgroup of goods and services causing an absolute growth in inflation rate greater than 1\%) are depicted in bold, the biggest "reducer" (expenditure on a given subgroup of goods and services causing an absolute fall in the inflation rate by more than 1\%) in bold italic. Columns 1-12 refer to the first level of COICOP categories and are listed below the tables in the notes.

Table 6. Contributors to inflation rate in absolute terms; how much each of the groups contributed to inflation rate

Whole sample

\begin{tabular}{|l|r|r|r|r|r|r|r|r|r|r|r|r|}
\hline & $\mathbf{1}$ & $\mathbf{2}$ & $\mathbf{3}$ & $\mathbf{4}$ & $\mathbf{5}$ & $\mathbf{6}$ & $\mathbf{7}$ & $\mathbf{8}$ & $\mathbf{9}$ & $\mathbf{1 0}$ & $\mathbf{1 1}$ & $\mathbf{1 2}$ \\
\hline $\mathbf{1 9 9 5}$ & $\mathbf{1 . 9 2} \%$ & $0.32 \%$ & $\mathbf{1 . 0 3} \%$ & $\mathbf{1 . 6 6}$ & $0.51 \%$ & $0.20 \%$ & $0.72 \%$ & $0.20 \%$ & $0.82 \%$ & $0.36 \%$ & $0.58 \%$ & $0.63 \%$ \\
\hline $\mathbf{1 9 9 6}$ & $\mathbf{1 . 5 9 \%}$ & $0.40 \%$ & $0.93 \%$ & $\mathbf{1 . 8 4 \%}$ & $0.31 \%$ & $0.21 \%$ & $\mathbf{1 . 6 7 \%}$ & $0.19 \%$ & $0.61 \%$ & $0.25 \%$ & $0.40 \%$ & $0.55 \%$ \\
\hline $\mathbf{1 9 9 7}$ & $0.77 \%$ & $0.27 \%$ & $0.79 \%$ & $\mathbf{2 . 8 0}$ & $0.40 \%$ & $0.31 \%$ & $\mathbf{1 . 0 5 \%}$ & $0.21 \%$ & $0.66 \%$ & $0.21 \%$ & $0.39 \%$ & $0.54 \%$ \\
\hline $\mathbf{1 9 9 8}$ & $\mathbf{1 . 0 0 \%}$ & $0.37 \%$ & $0.54 \%$ & $\mathbf{4 . 8 1 \%}$ & $0.39 \%$ & $0.22 \%$ & $0.58 \%$ & $0.21 \%$ & $0.67 \%$ & $0.29 \%$ & $0.52 \%$ & $0.53 \%$ \\
\hline $\mathbf{1 9 9 9}$ & $-0.64 \%$ & $0.12 \%$ & $0.05 \%$ & $\mathbf{1 . 2 0} \%$ & $0.09 \%$ & $0.05 \%$ & $0.32 \%$ & $0.27 \%$ & $0.05 \%$ & $0.13 \%$ & $0.11 \%$ & $0.13 \%$ \\
\hline $\mathbf{2 0 0 0}$ & $0.13 \%$ & $0.12 \%$ & $-0.15 \%$ & $\mathbf{1 . 6 8 \%}$ & $0.00 \%$ & $0.04 \%$ & $\mathbf{1 . 1 7} \%$ & $0.15 \%$ & $0.23 \%$ & $0.03 \%$ & $0.13 \%$ & $0.24 \%$ \\
\hline $\mathbf{2 0 0 1}$ & $0.84 \%$ & $0.11 \%$ & $-0.15 \%$ & $\mathbf{2 . 5 4 \%}$ & $0.00 \%$ & $0.06 \%$ & $-0.04 \%$ & $0.21 \%$ & $0.46 \%$ & $0.02 \%$ & $0.19 \%$ & $0.35 \%$ \\
\hline $\mathbf{2 0 0 2}$ & $-0.44 \%$ & $0.06 \%$ & $-0.20 \%$ & $\mathbf{1 . 1 3 \%}$ & $-0.01 \%$ & $0.08 \%$ & $-0.32 \%$ & $0.05 \%$ & $0.14 \%$ & $0.03 \%$ & $0.21 \%$ & $0.23 \%$ \\
\hline $\mathbf{2 0 0 3}$ & $-0.43 \%$ & $0.04 \%$ & $-0.51 \%$ & $0.28 \%$ & $-0.16 \%$ & $0.10 \%$ & $0.06 \%$ & $-0.23 \%$ & $-0.16 \%$ & $0.03 \%$ & $0.15 \%$ & $0.42 \%$ \\
\hline $\mathbf{2 0 0 4}$ & $0.52 \%$ & $0.11 \%$ & $-0.34 \%$ & $0.63 \%$ & $-0.17 \%$ & $0.12 \%$ & $0.38 \%$ & $0.59 \%$ & $-0.01 \%$ & $0.02 \%$ & $0.36 \%$ & $0.29 \%$ \\
\hline $\mathbf{2 0 0 5}$ & $-0.06 \%$ & $0.04 \%$ & $-0.35 \%$ & $0.93 \%$ & $-0.16 \%$ & $0.16 \%$ & $0.22 \%$ & $0.24 \%$ & $0.04 \%$ & $0.02 \%$ & $0.27 \%$ & $-0.01 \%$ \\
\hline $\mathbf{2 0 0 6}$ & $0.16 \%$ & $0.03 \%$ & $-0.39 \%$ & $\mathbf{1 . 6 6 \%}$ & $-0.11 \%$ & $0.10 \%$ & $0.21 \%$ & $0.23 \%$ & $0.03 \%$ & $0.03 \%$ & $0.21 \%$ & $0.04 \%$ \\
\hline $\mathbf{2 0 0 7}$ & $0.69 \%$ & $0.33 \%$ & $-0.05 \%$ & $\mathbf{1 . 0 3 \%}$ & $-0.03 \%$ & $0.11 \%$ & $0.02 \%$ & $-0.04 \%$ & $-0.04 \%$ & $0.02 \%$ & $0.19 \%$ & $0.04 \%$ \\
\hline $\mathbf{2 0 0 8}$ & $\mathbf{1 . 1 8 \%}$ & $0.30 \%$ & $-0.08 \%$ & $\mathbf{2 . 8 9 \%}$ & $0.03 \%$ & $0.79 \%$ & $0.31 \%$ & $-0.15 \%$ & $0.05 \%$ & $0.02 \%$ & $0.44 \%$ & $0.29 \%$ \\
\hline $\mathbf{2 0 0 9}$ & $0.18 \%$ & $0.14 \%$ & $-0.17 \%$ & $0.43 \%$ & $-0.05 \%$ & $0.20 \%$ & $0.48 \%$ & $-0.12 \%$ & $-0.20 \%$ & $0.01 \%$ & $0.15 \%$ & $0.01 \%$ \\
\hline $\mathbf{2 0 1 0}$ & $0.17 \%$ & $0.14 \%$ & $-0.16 \%$ & $0.46 \%$ & $-0.05 \%$ & $0.19 \%$ & $0.47 \%$ & $-0.12 \%$ & $-0.16 \%$ & $0.01 \%$ & $0.15 \%$ & $0.01 \%$ \\
\hline
\end{tabular}

\section{Pensioner sample}

\begin{tabular}{|l|r|r|r|r|r|r|r|r|r|r|r|r|}
\hline & $\mathbf{1}$ & $\mathbf{2}$ & $\mathbf{3}$ & $\mathbf{4}$ & $\mathbf{5}$ & $\mathbf{6}$ & $\mathbf{7}$ & $\mathbf{8}$ & $\mathbf{9}$ & $\mathbf{1 0}$ & $\mathbf{1 1}$ & $\mathbf{1 2}$ \\
\hline $\mathbf{1 9 9 5}$ & $\mathbf{4 . 2 5 \%}$ & $0.24 \%$ & $0.52 \%$ & $\mathbf{2 . 3 8 \%}$ & $0.28 \%$ & $0.25 \%$ & $0.40 \%$ & $0.26 \%$ & $0.41 \%$ & $0.20 \%$ & $0.29 \%$ & $0.33 \%$ \\
\hline $\mathbf{1 9 9 6}$ & $\mathbf{3 . 5 6 \%}$ & $0.31 \%$ & $0.50 \%$ & $\mathbf{2 . 6 4 \%}$ & $0.20 \%$ & $0.27 \%$ & $\mathbf{1 . 0 1 \%}$ & $0.22 \%$ & $0.30 \%$ & $0.13 \%$ & $0.21 \%$ & $0.33 \%$ \\
\hline $\mathbf{1 9 9 7}$ & $\mathbf{1 . 7 8 \%}$ & $0.24 \%$ & $0.48 \%$ & $\mathbf{4 . 1 7} \%$ & $0.30 \%$ & $0.35 \%$ & $0.72 \%$ & $0.27 \%$ & $0.61 \%$ & $0.10 \%$ & $0.19 \%$ & $0.36 \%$ \\
\hline $\mathbf{1 9 9 8}$ & $\mathbf{1 . 4 0 \%}$ & $0.34 \%$ & $0.32 \%$ & $\mathbf{7 . 1 1 \%}$ & $0.38 \%$ & $0.29 \%$ & $0.38 \%$ & $0.25 \%$ & $0.58 \%$ & $0.13 \%$ & $0.27 \%$ & $0.45 \%$ \\
\hline $\mathbf{1 9 9 9}$ & $\mathbf{- 1 . 9 3 \%}$ & $0.13 \%$ & $0.04 \%$ & $\mathbf{2 . 2 7} \%$ & $0.12 \%$ & $0.07 \%$ & $0.29 \%$ & $0.39 \%$ & $0.15 \%$ & $0.08 \%$ & $0.08 \%$ & $0.13 \%$ \\
\hline $\mathbf{2 0 0 0}$ & $0.27 \%$ & $0.09 \%$ & $-0.08 \%$ & $\mathbf{2 . 8 6 \%}$ & $0.03 \%$ & $0.04 \%$ & $0.22 \%$ & $0.20 \%$ & $0.21 \%$ & $0.00 \%$ & $0.08 \%$ & $0.14 \%$ \\
\hline $\mathbf{2 0 0 1}$ & $\mathbf{1 . 5 9 \%}$ & $0.11 \%$ & $-0.05 \%$ & $\mathbf{3 . 0 4 \%}$ & $-0.01 \%$ & $0.10 \%$ & $0.03 \%$ & $0.19 \%$ & $0.47 \%$ & $0.00 \%$ & $0.07 \%$ & $0.31 \%$ \\
\hline $\mathbf{2 0 0 2}$ & $-0.55 \%$ & $0.06 \%$ & $-0.09 \%$ & $\mathbf{1 . 4 0 \%}$ & $0.00 \%$ & $0.12 \%$ & $-0.19 \%$ & $0.12 \%$ & $0.19 \%$ & $0.00 \%$ & $0.08 \%$ & $0.25 \%$ \\
\hline $\mathbf{2 0 0 3}$ & $-0.65 \%$ & $0.04 \%$ & $-0.20 \%$ & $0.27 \%$ & $-0.10 \%$ & $0.11 \%$ & $0.03 \%$ & $-0.08 \%$ & $0.08 \%$ & $0.00 \%$ & $0.05 \%$ & $0.27 \%$ \\
\hline $\mathbf{2 0 0 4}$ & $\mathbf{1 . 0 1 \%}$ & $0.09 \%$ & $-0.15 \%$ & $0.83 \%$ & $-0.11 \%$ & $0.11 \%$ & $0.15 \%$ & $0.61 \%$ & $0.15 \%$ & $0.00 \%$ & $0.18 \%$ & $0.23 \%$ \\
\hline $\mathbf{2 0 0 5}$ & $-0.10 \%$ & $0.02 \%$ & $-0.20 \%$ & $\mathbf{1 . 3 1 \%}$ & $-0.15 \%$ & $0.28 \%$ & $0.20 \%$ & $0.31 \%$ & $0.17 \%$ & $0.00 \%$ & $0.11 \%$ & $0.01 \%$ \\
\hline $\mathbf{2 0 0 6}$ & $0.28 \%$ & $0.03 \%$ & $-0.22 \%$ & $\mathbf{2 . 2 1 \%}$ & $-0.09 \%$ & $0.16 \%$ & $0.14 \%$ & $0.27 \%$ & $0.19 \%$ & $0.00 \%$ & $0.08 \%$ & $0.06 \%$ \\
\hline $\mathbf{2 0 0 7}$ & $\mathbf{1 . 1 8 \%}$ & $0.20 \%$ & $-0.02 \%$ & $\mathbf{1 . 0 2 \%}$ & $-0.03 \%$ & $0.15 \%$ & $0.06 \%$ & $0.01 \%$ & $0.13 \%$ & $0.00 \%$ & $0.07 \%$ & $0.05 \%$ \\
\hline $\mathbf{2 0 0 8}$ & $\mathbf{2 . 1 7 \%}$ & $0.22 \%$ & $-0.04 \%$ & $\mathbf{3 . 5 2} \%$ & $0.01 \%$ & $\mathbf{1 . 0 2} \%$ & $0.25 \%$ & $-0.06 \%$ & $0.20 \%$ & $0.00 \%$ & $0.20 \%$ & $0.24 \%$ \\
\hline $\mathbf{2 0 0 9}$ & $0.33 \%$ & $0.12 \%$ & $-0.08 \%$ & $0.46 \%$ & $-0.04 \%$ & $0.30 \%$ & $0.42 \%$ & $-0.08 \%$ & $-0.09 \%$ & $0.00 \%$ & $0.07 \%$ & $0.04 \%$ \\
\hline $\mathbf{2 0 1 0}$ & $0.31 \%$ & $0.13 \%$ & $-0.08 \%$ & $0.50 \%$ & $-0.04 \%$ & $0.29 \%$ & $0.25 \%$ & $-0.08 \%$ & $-0.09 \%$ & $0.00 \%$ & $0.07 \%$ & $0.04 \%$ \\
\hline
\end{tabular}


Low-income sample

\begin{tabular}{|l|r|r|r|r|r|r|r|r|r|r|r|r|}
\hline & $\mathbf{1}$ & $\mathbf{2}$ & $\mathbf{3}$ & $\mathbf{4}$ & $\mathbf{5}$ & $\mathbf{6}$ & $\mathbf{7}$ & $\mathbf{8}$ & $\mathbf{9}$ & $\mathbf{1 0}$ & $\mathbf{1 1}$ & $\mathbf{1 2}$ \\
\hline $\mathbf{1 9 9 5}$ & $\mathbf{3 . 7 4 \%}$ & $0.24 \%$ & $0.74 \%$ & $\mathbf{2 . 0 1 \%}$ & $0.29 \%$ & $0.12 \%$ & $0.34 \%$ & $0.14 \%$ & $0.44 \%$ & $0.27 \%$ & $0.39 \%$ & $0.41 \%$ \\
\hline $\mathbf{1 9 9 6}$ & $\mathbf{3 . 5 1 \%}$ & $0.36 \%$ & $0.66 \%$ & $\mathbf{2 . 3 3 \%}$ & $0.18 \%$ & $0.14 \%$ & $\mathbf{1 . 2 1 \%}$ & $0.15 \%$ & $0.31 \%$ & $0.17 \%$ & $0.29 \%$ & $0.40 \%$ \\
\hline $\mathbf{1 9 9 7}$ & $\mathbf{1 . 6 6 \%}$ & $0.24 \%$ & $0.65 \%$ & $\mathbf{3 . 5 4 \%}$ & $0.29 \%$ & $0.21 \%$ & $0.66 \%$ & $0.20 \%$ & $0.48 \%$ & $0.15 \%$ & $0.35 \%$ & $0.49 \%$ \\
\hline $\mathbf{1 9 9 8}$ & $\mathbf{1 . 4 1 \%}$ & $0.31 \%$ & $0.32 \%$ & $\mathbf{7 . 8 0 \%}$ & $0.35 \%$ & $0.28 \%$ & $0.38 \%$ & $0.26 \%$ & $0.55 \%$ & $0.13 \%$ & $0.32 \%$ & $0.45 \%$ \\
\hline $\mathbf{1 9 9 9}$ & $\mathbf{- 1 . 8 7 \%}$ & $0.12 \%$ & $0.03 \%$ & $\mathbf{2 . 8 2} \%$ & $0.11 \%$ & $0.06 \%$ & $0.11 \%$ & $0.42 \%$ & $0.14 \%$ & $0.05 \%$ & $0.09 \%$ & $0.14 \%$ \\
\hline $\mathbf{2 0 0 0}$ & $0.27 \%$ & $0.09 \%$ & $-0.08 \%$ & $\mathbf{2 . 8 6 \%}$ & $0.03 \%$ & $0.04 \%$ & $0.22 \%$ & $0.20 \%$ & $0.21 \%$ & $0.00 \%$ & $0.08 \%$ & $0.14 \%$ \\
\hline $\mathbf{2 0 0 1}$ & $\mathbf{1 . 7 8 \%}$ & $0.11 \%$ & $-0.07 \%$ & $\mathbf{3 . 7 8 \%}$ & $0.00 \%$ & $0.07 \%$ & $0.05 \%$ & $0.22 \%$ & $0.26 \%$ & $0.00 \%$ & $0.11 \%$ & $0.19 \%$ \\
\hline $\mathbf{2 0 0 2}$ & $-0.57 \%$ & $0.05 \%$ & $-0.11 \%$ & $\mathbf{1 . 9 3} \%$ & $0.02 \%$ & $0.13 \%$ & $0.00 \%$ & $0.17 \%$ & $0.23 \%$ & $0.01 \%$ & $0.13 \%$ & $0.13 \%$ \\
\hline $\mathbf{2 0 0 3}$ & $-0.62 \%$ & $0.02 \%$ & $-0.19 \%$ & $0.37 \%$ & $-0.07 \%$ & $0.10 \%$ & $0.03 \%$ & $-0.09 \%$ & $0.06 \%$ & $0.00 \%$ & $0.05 \%$ & $0.18 \%$ \\
\hline $\mathbf{2 0 0 4}$ & $\mathbf{1 . 0 1 \%}$ & $0.09 \%$ & $-0.15 \%$ & $0.83 \%$ & $-0.11 \%$ & $0.11 \%$ & $0.15 \%$ & $0.61 \%$ & $0.15 \%$ & $0.00 \%$ & $0.18 \%$ & $0.23 \%$ \\
\hline $\mathbf{2 0 0 5}$ & $-0.11 \%$ & $0.03 \%$ & $-0.20 \%$ & $\mathbf{1 . 5 4 \%}$ & $-0.12 \%$ & $0.27 \%$ & $0.10 \%$ & $0.36 \%$ & $0.21 \%$ & $0.00 \%$ & $0.14 \%$ & $0.04 \%$ \\
\hline $\mathbf{2 0 0 6}$ & $0.31 \%$ & $0.03 \%$ & $-0.23 \%$ & $\mathbf{2 . 6 8 \%}$ & $-0.07 \%$ & $0.16 \%$ & $0.10 \%$ & $0.30 \%$ & $0.24 \%$ & $0.01 \%$ & $0.08 \%$ & $0.04 \%$ \\
\hline $\mathbf{2 0 0 7}$ & $\mathbf{1 . 2 5 \%}$ & $0.25 \%$ & $-0.02 \%$ & $\mathbf{1 . 3 5 \%}$ & $0.00 \%$ & $0.13 \%$ & $0.05 \%$ & $0.00 \%$ & $0.18 \%$ & $0.00 \%$ & $0.09 \%$ & $0.04 \%$ \\
\hline $\mathbf{2 0 0 8}$ & $\mathbf{2 . 2 2 \%}$ & $0.21 \%$ & $-0.04 \%$ & $\mathbf{3 . 7 6 \%}$ & $0.01 \%$ & $0.96 \%$ & $0.22 \%$ & $-0.06 \%$ & $0.21 \%$ & $0.00 \%$ & $0.23 \%$ & $0.24 \%$ \\
\hline $\mathbf{2 0 0 9}$ & $0.34 \%$ & $0.11 \%$ & $-0.08 \%$ & $0.79 \%$ & $-0.04 \%$ & $0.29 \%$ & $0.22 \%$ & $-0.10 \%$ & $-0.04 \%$ & $0.00 \%$ & $0.09 \%$ & $0.00 \%$ \\
\hline $\mathbf{2 0 1 0}$ & $0.29 \%$ & $0.12 \%$ & $-0.08 \%$ & $0.73 \%$ & $-0.04 \%$ & $0.25 \%$ & $0.21 \%$ & $-0.09 \%$ & $-0.01 \%$ & $0.00 \%$ & $0.09 \%$ & $0.00 \%$ \\
\hline
\end{tabular}

Notes: Columns 1-12 refer to the first level of COICOP categories: 1. Food, Non-Alcoholic Beverages; 2. Alcoholic Beverages, Tobacco; 3. Clothing, Footwear; 4. Housing, Water, Electricity, Gas, Other Fuels; 5. Furnishings, Household Equipment, Routine Household Maintenance; 6. Health; 7. Transport; 8. Communication; 9. Recreation, Culture; 10. Education; 11. Restaurants, Hotels; 12. Miscellaneous Goods, Services

For the whole sample, the most common "increaser" of the inflation rate was expenditure on housing and energy, because its price index rose very fast, and expenditure on food and non-alcoholic drinks, because this was the biggest expenditure group. The same holds for both subgroups. These two groups of expenditure increased the subgroup inflation rate by more than 1 percentage point in twelve years and in eight years, respectively. Comparing the magnitudes, both these expenditure groups had a greater absolute impact on the two subgroups' inflation rates than on the aggregate one. This can be explained by the fact that both subgroups spend relatively more on these expenditure groups. Expenditure on transport was an "increaser" three times for the whole sample in the period 1995-2000, but only in 1996 for both the subgroups, because the subgroups spent relatively little on transport. Comparing the results for pensioner and low-income samples, the structure of "increasers" for both subgroups seems very similar with one minor exception - in 2008, pensioner expenditure for health caused the pensioner inflation rate to grow by $1.02 \%$, whereas for low-income households it was $0.96 \%$. We observe that there are no "reducers" with the one exception of food and non-alcoholic drinks expenditure for both subgroups in 1999.

The CZSO should consider constructing subgroup indices, ideally with regional variance, so as to be able to better distinguish the inflation rates faced by individual households. Some national statistical offices are already issuing subgroup indices (i.e. the US Bureau of Labor Statistics, as mentioned by Stewart (2008, page 19), the Indian Ministry of Statistics and Programme Implementation and the Hong Kong Census and Statistics Department, as discussed by Ley (2005, pages 634 and 641)). The question of exactly which and how many different price indices should be evaluated by the CZSO for the purposes of economic policy remains unanswered, and is beyond the scope of this paper. The introduction of more price indices should enable policy makers to design economic policies more precisely and therefore contribute to better evidence-based policy making. However, since many Czech 
citizens do not even understand the meaning of the one, official, inflation rate, the cost of introducing this more detailed indexing might induce a higher level of public misunderstanding.

Areas for further research include the analysis of further subgroups and of the impact of price shocks on various inflation rates. Combining the data and methods used here with information on real wages and other indicators would be also very useful and would provide a more complex picture of developments in the living standards of various households.

Further research could make estimating the impact not only of inflation, but monetary policy more generally as well-established an exercise as that for fiscal policy, as demonstrated, for example, in Lustig et al. (2012) and Cormac \& Preston (2012). A step in this direction is, for example, Romer \& Romer (1998). Further, estimates of distributional impact of other policies would benefit from further research, ranging from fiscal consolidation in Ball et al. (2013) to globalisation in Goldberg \& Pavcnik (2007).

\section{Conclusion}

This article has analysed the heterogeneity of household-specific inflation rates in the Czech Republic between 1995 and 2010. For this analysis we have used the most detailed data available on households, and on the prices of various goods and services, both nationwide and in the Prague region. By linking expenditure items with their respective price indices, we estimated the specific inflation rate for every household in the sample, which also enabled us to estimate subgroup inflation rates. We hope this analysis will attract increased attention to the often-neglected microeconomic implications of one of the most important macroeconomic variables.

We have found that around $60 \%$ of the Czech households studied experienced an inflation rate within 1 percentage point of the national average inflation rate, and have further found a negative association between the average inflation rate and representativeness: the higher the magnitude of the average inflation rate over time, the lower the percentage of households who experience an inflation rate similar to the average. Our results also show that using the Prague-specific prices in calculations would result in lower inflation rates being reported for Prague households, which would better reflect the reality experienced by those Prague households. This implies that a bias is introduced when assuming that households from all regions face the same, nationwide prices. Before making specific policy recommendations, however, we suggest estimation of similar results for other regions and accounting for the differences not only in changes in prices, but also in price levels, both in cooperation with the Czech Statistical Office.

We have compared the democratic and plutocratic average inflation rates and have demonstrated that the democratic average is more suitable for analysis of inflation differentials for subgroups of low-income and pensioner households. The average democratic inflation rates of these two subgroups are higher than the aggregate rate in all years except for 1999. For these two subgroup rates we identified the following determiners of high inflation: expenditure on housing, water, electricity, gas, and other fuels, and expenditure on food and non-alcoholic beverages. 
Since the results presented here are the first of their kind for the Czech Republic and the results from previously published studies vary quite significantly across countries, our results may not necessarily have predictive power for the forthcoming years. Therefore, the results warrant regular updating and policy-makers should be relatively cautious and should not rely solely on our estimates.

The cumulative inflation from 1994 to 2010 was estimated at 209\% for pensioner households, and $213 \%$ for low-income households, in contrast to $193 \%$ for the whole sample. These differences could serve as a signal to Czech policy makers to begin applying knowledge of differences between subgroup inflation rates in their designs for evidencebased policies. Applying this approach to the indexation of pensions and social benefits would be a good starting point. For example, a new indexation of pensions that would be dependent on pensioner-specific inflation rates, rather than on aggregate rates, could be considered. Of course, this kind of indexation, similarly to other detailed adjustments, has implementation and operation costs that need to be weighed against the possible benefits.

\section{References}

Abraham, K. G., Greenlees, J. S., \& Moulton, B. R. (1998). Working to improve the consumer price index. The Journal of Economic Perspectives, 12(1), 27-36.

Artsev, Y., Roshal, V., \& Finkel, Y. (2006). Consumer Price Indices-Measuring Across Households. In Ninth Ottawa Group Meeting on Prices, London. Retrieved from http://www.ottawagroup.org/Ottawa/ottawagroup.nsf/home/Meeting+9/\$file/2006 \%209th\%20Meeting\%20-\%20Yoel\%20Finkel\%20-\%20CPI\%20-

\%20aggregating\%20across\%20households.pdf

Ball, L., Davide, F., Leigh, D., \& Loungani, P. (2013). The Distributional Effects of Fiscal Consolidation. IMF Working Paper. Retrieved from http://www.imf.org/external/pubs/cat/longres.aspx?sk=40699.0

Blank, R. M., \& Blinder, A. S. (1985). Macroeconomics, income distribution, and poverty. National Bureau of Economic Research Cambridge, Mass., USA. Retrieved from http://www.nber.org/papers/w1567

Boskin, M. J., Dulberger, E. R., Gordon, R. J., Griliches, Z., \& Jorgenson, D. W. (1998). Consumer prices, the consumer price index, and the cost of living. The Journal of Economic Perspectives, 12(1), 3-26.

Crawford, I., \& Smith, Z. (2002). Distributional aspects of inflation. IFS, Commentary 90. Retrieved from http://www.ifs.org.uk/comms/comm90.pdf

Czech Statistical Office. (2013). Consumer Price Indices: Methodological Manual. Czech Statistical Office. Retrieved from http://www.czso.cz/eng/redakce.nsf/i/cpi_users_methodological_manual/\$File/man ual_isc_2013en.pdf

Čadil, J., Mazouch, P., Musil, P., \& Kramulová, J. (2012). Application of Regional Price Levels on Estimation of Regional Macro-Aggregates Per Capita in PPS. Statistika, 49(4). 
Retrieved from

http://www.regionalstudies.org/uploads/conferences/presentations/europeanconference-2012/presentations/cadil-et-al.pdf

Davies, R., \& Wilson, R. A. (2002). Assembly Scrutiny of London Weighting. Warwick Institute for Employment Research.

Dušek, L., \& Janský, P. (2012). Changes in value added tax: how much do they affect households? (Změny daně $z$ přidané hodnoty: Kolik přidají nebo uberou domácnostem?). Politická ekonomie, (3).

Dybczak, K., Tóth, P., \& Voňka, D. (2010). Effects of Price Shocks to Consumer Demand. Estimating the QUAIDS Demand System on Czech Household Budget Survey Data. Working Papers.

Bogaert et. al. (2009). Dealing with the impact of an ageing population in the EU. Ageing Report 2009.

European Communities. (2004). Household Budget Survey in the Candidate Countries. Luxembourg: Office for Official Publications of the European Communities. Retrieved from http://epp.eurostat.ec.europa.eu/cache/ITY_SDDS/Annexes/hbs_esms_an3.pdf

Fernández, J. J. (2012). Explaining the introduction of automatic pension indexation provisions in 17 OECD countries, 1945-2000. Journal of European Social Policy, 22(3), 241-258.

Garner, T. I., Johnson, D. S., \& Kokoski, M. F. (1996). An Experimental Consumer Price Index for the Poor. Monthly Lab. Rev., 119, 32.

Garvey, E., \& Murphy, E. (2004). A consumer price index for low-income households in Ireland (1989-2001). Combat Poverty Agency.

Goldberg, P. K., \& Pavcnik, N. (2007). Distributional Effects of Globalization in Developing Countries (Working Paper No. 12885). National Bureau of Economic Research. Retrieved from http://www.nber.org/papers/w12885

Greenlees, J. S., \& Mason, C. C. (1996). Overview of the 1998 revision of the Consumer Price Index. Monthly Lab. Rev., 119, 3.

Hagemann, R. P. (1982). The variability of inflation rates across household types. journal of Money, Credit and Banking, 14(4), 494-510.

Hobijn, B., \& Lagakos, D. (2005). Inflation inequality in the United States. Review of Income and Wealth, 51(4), 581-606.

Kokoski, M. (2000). Alternative CPI aggregations: two approaches. Monthly Lab. Rev., 123, 31. 
Leicester, A., O'Dea, C., \& Oldfield, Z. (2008). The Inflation Experience of Older Households. Institute For Fiscal Studies. Commentary, (106). Retrieved from http://www.ifs.org.uk/comms/comm106.pdf

Ley, E. (2005). Whose inflation? A characterization of the CPI plutocratic gap. Oxford Economic Papers, 57(4), 634-646.

Lieu, P.-T., Chang, C., \& Chang, J. (2004). inflation rate Variations across household: empirical evidence from taiwan. international Journal of Business, 9(1). Retrieved from http://papers.ssrn.com/sol3/papers.cfm?abstract_id=490457

Lustig, N., Gray-Molina, G., Higgins, S., Jaramillo, M., Jiménez, W., Paz, V., ... Yañez, E. (2012). The Impact of Taxes and Social Spending on Inequality and Poverty in Argentina, Bolivia, Brazil, Mexico, and Peru: A Synthesis of Results. Center for Global Development Working Paper, 311. Retrieved from http://cgdev.org/files/1426706_file_Lustig_et_al_Impact_of_Taxes.pdf

Moulton, B. R., \& Stewart, K. J. (1999). An overview of experimental US consumer price indexes. Journal of Business \& Economic Statistics, 17(2), 141-151.

O'Dea, C., \& Preston, I. P. (2012). The distributional impact of public spending in the UK (IFS Working Paper No. W12/06). Institute for Fiscal Studies. Retrieved from http://econpapers.repec.org/paper/ifsifsewp/12_2f06.htm

O’Donoghue, J., Powell, M., \& Fenwick, D. (2007). Personal Inflation: Perception and Experiences. Office for National Statistics, United Kingdom. Retrieved from http://www.ottawagroup.org/Ottawa/ottawagroup.nsf/4a256353001af3ed4b2562b b00121564/ca8009e582a0c66dca257577007fbcd0/\$FILE/2007\%2010th\%20meeting $\% 20-$

\%20David\%20Fenwick\%20(ONS)_Jim\%200\%E2\%80\%99Donoghue,\%20Matthew\%20P owell\%20and\%20David\%20Fenwick_Personal\%20Inflation_Perceptions\%20And\%20E xperiences.pdf

Oosthuizen, M. (2007). Consumer Price Inflation across the Income Distribution in South Africa. Retrieved from http://ideas.repec.org/p/ctw/wpaper/07129.html

Prais, S. J. (1959). Whose cost of living? The review of economic studies, 26(2), 126-134.

Romer, C. D., \& Romer, D. H. (1998). Monetary Policy and the Well-Being of the Poor (Working Paper No. 6793). National Bureau of Economic Research. Retrieved from http://www.nber.org/papers/w6793

Ruiz-Castillo, J., Ley, E., \& Izquierdo, M. (1999). The plutocratic bias in the CPI: Evidence from Spain. No.: Documento de trabajo 1999-15. Retrieved from http://earchivo.uc3m.es/handle/10016/4731

Snyder, E. M. (1961). Cost of Living Indexes for Special Classes of Consumers. The Price Statistics of the Federal Government (National Bureau of Economic Research, No. 73, General Series, 1961). 
Stewart, K. J. (2008). Experimental consumer price index for elderly americans (cpi-e): 19822007, the. Monthly Lab. Rev., 131, 19.

Sugema, I., Irfany, M. I., Holis, A., \& Bakhtiar, T. (2010). Consumer Price Index for the Poor (CPI-P): An Empirical Analysis of Indonesia.

Webb, R. H., \& Willense, H. (1995). Macroeconomic Price Indixes. In Macroeconomic Data: A User's guide. The Federal Reserve Bank of Richmond. Retrieved from https://www.richmondfed.org/publications/research/special_reports/macroeconomi c_data/

Whitehouse, E. R. (2009). Pensions, purchasing-power risk, inflation and indexation. OECD Publishing. Retrieved from http://develop.fafo.no/files/news/9282/5Pensions,\%20PurchasingPower\%20Risk,\%20Inflation\%20and\%20Indexation.pdf 


\section{Working Paper Series}

ISSN 1211-3298

Registration No. (Ministry of Culture): E 19443

Individual researchers, as well as the on-line and printed versions of the CERGE-EI Working Papers (including their dissemination) were supported from institutional support RVO 67985998 from Economics Institute of the ASCR, v. v. i.

Specific research support and/or other grants the researchers/publications benefited from are acknowledged at the beginning of the Paper.

(c) Pavel Hait and Petr Janský, 2014

All rights reserved. No part of this publication may be reproduced, stored in a retrieval system or transmitted in any form or by any means, electronic, mechanical or photocopying, recording, or otherwise without the prior permission of the publisher.

Published by

Charles University in Prague, Center for Economic Research and Graduate Education (CERGE) and

Economics Institute of the ASCR, v. v. i. (EI)

CERGE-El, Politických vězňů 7, 11121 Prague 1, tel.: +420 224005 153, Czech Republic.

Printed by CERGE-EI, Prague

Subscription: CERGE-EI homepage: http://www.cerge-ei.cz

Phone: + 420224005153

Email: office@cerge-ei.cz

Web: http://www.cerge-ei.cz

Editor: Marek Kapička

The paper is available online at http://www.cerge-ei.cz/publications/working_papers/.

ISBN 978-80-7343-312-3 (Univerzita Karlova. Centrum pro ekonomický výzkum a doktorské studium)

ISBN 978-80-7344-305-4 (Akademie věd České republiky. Národohospodářský ústav) 
CERGE-EI

P.O.BOX 882

Politických vězňů 7

11121 Praha 1

Czech Republic http://www.cerge-ei.cz 